\title{
Probléma megoldási módszerek egy térgeometriai feladat kapcsán
}

\author{
Barta Edit \\ Soproni Egyetem Matematikai Intézet \\ barta.edit@uni-sopron.hu
}

\begin{abstract}
ÖSSZEFOGLALÓ. Egy térgeometriai feladaton keresztül szeretném bemutatni azokat a probléma megoldási módszereket, gondolkodási módokat, amelyeket az élet különböző területein dolgozó, munkájuk során konstruktív gondolkozást igénylö feladatokkal találkozó emberek alkalmaznak, ha egy-egy problémával találkoznak. A példán keresztül arra is szeretnék rámutatni, hogy egy-egy kézzelfogható feladattal hogyan tehetjük színesebbé, érdekesebbé az integrálszámítás oktatását.
\end{abstract}

ABSTRACT. We show how people working in different fields use different thinking methods and problem solving skills for figuring out the same spatial geometrical exercise. We also point out that a real life problem can give a challenge in teaching integral calculus.

\section{Bevezetés}

Ennek a cikknek az ötletét egy magam által megélt történet adta. Néhány évvel ezelőtt közvetlen kollégáim körében valaki felvetett egy térgeometriai feladatot, amelynek az eredete számomra nem ismert. Egy kockát két lappárjára merőlegesen átfúrunk egy-egy hengerrel úgy, hogy a henger palástja érinti a kocka másik négy oldalát. Mekkora az így megmaradó test térfogatának és az eredeti kocka térfogatának a hányadosa? Többünk fantáziáját megmozgatta a feladat, de végül csak hárman foglalkoztunk a problémával, és jutottunk el a megoldásig: a technikus, a faipari mérnökhallgató és a matematika-fizika szakos tanár. Megoldásunk szinte viccbe illő, legalább is alátámasztja azokat a vicceket, amelyek a matematikusok körülményes gondolkodásmódját állítják középpontba szemben a mérnök frappáns megoldásaival. Oldalakat számoltam teleírva integráljelekkel, többször is mellékútra tévedve, míg kikristályosodott a legrövidebb megoldás. A technikus rövid matematikai próbálkozás után elkészítette a kérdéses testet, és tömegméréssel jutott helyes eredményre. A mérnökhallgató pedig leült a számítógép elé, és egy tervezőprogram segítségével megrajzolta az átfúrt kockát, majd kiszámoltatta a megmaradó rész térfogatát. Itt elsősorban a saját, matematikai megoldásaimat szeretném ismertetni a mellékutak nélkül. Egyik célom az, hogy rámutassak arra, hogy a túlságosan száraznak tünő integrálszámítási tananyagot igenis van lehetősége az oktatónak élettel feltölteni, érdekesebbé, színesebbé tenni egy-egy ilyen feladattal.

\section{A feladat és a megoldások ismertetése}

\section{A feladat}

Egy kockát henger alakú lyukkal átfúrunk az egyik szemközti lappárjára merőlegesen úgy, hogy a lyuk tengelye egybeesik a kocka ezen lappárjára merőleges szimmetriatenge- 
lyével, és érinti a kocka másik négy oldalát. Ezek után ugyanilyen lyukat fúrunk egy másik lappárra merölegesen is. Hányad része a kocka így megmaradó térfogata az eredeti térfogatának?

\section{A ,matematikus” megoldásai.}

Először a megoldás menetét találjuk ki! Ha a kocka térfogatából kivonjuk az egyik henger térfogatát majd a másikét, akkor a két henger közös részének térfogatát kétszer vontuk ki, tehát azt még hozzá kell adni az eredményhez. Egyfajta szita-formulával:

$$
V_{\text {megmaradó }}=V_{\text {kocka }}-2 V_{\text {henger }}+V_{\text {közös }} \text {. }
$$

A kocka és a henger térfogata jól ismert képlettel számítható, tehát a feladat kulcsa a két henger közös részének meghatározása. Erre több lehetőség is kínálkozik, ezek közül szeretnék néhányat bemutatni. Először érdemes a testet elképzelni, vázlatosan megrajzolni. Már itt felmerül az első probléma. A háromdimenziós test két dimenzióban való szabadkézi megrajzolása kissé nehézkes, jó térlátást igényel, ámde a hallgatóknak többnyire ez az egyetlen lehetőség áll rendelkezésre, föleg ha akkor hallják elöször a feladatot, és ott helyben órán meg is kell oldani. Úgy vélem, pedagógiailag helyesebb, ha az oktató is szabadkézzel rajzolja fel a táblára. A kész ábrák kivetítése látványosabb ugyan, de hitelesebb és könnyebben követhető a valós időben felrajzolt ábra. Ennek ellenére jelen cikkben a szemléltető ábrák számítógéppel készültek.

A feladatot legkézenfekvőbb integrálszámítással megoldani. Elöször helyezzük el a két átható hengert a háromdimenziós derékszögü koordináta-rendszerben. Erre két lehetőség kínálkozik, melyeket az 1. ábra szemléltet.
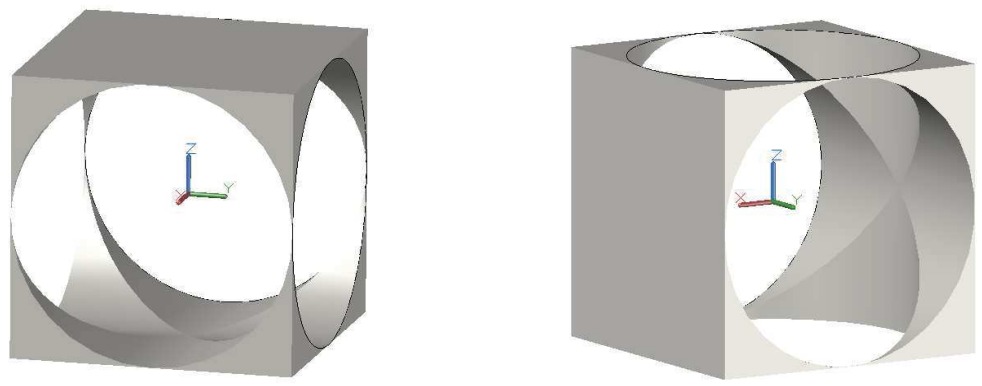

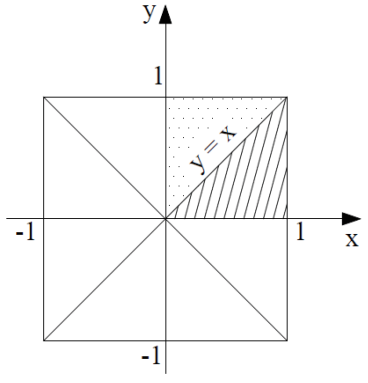

a)

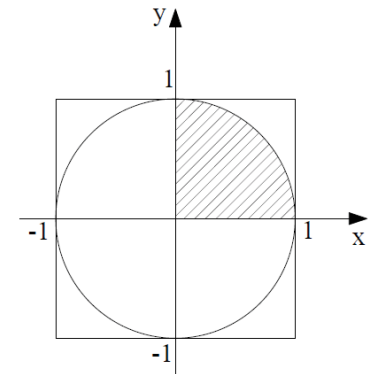

b)

1. ábra. A test elhelyezése a koordináta-rendszerben és vetülete az $x y$-síkra

Az origót mindkét esetben a kocka középpontjába helyeztük. Szimmetria okok miatt a közös rész térfogatát elegendő az $x y$-sík pozitív síknegyede felett kiszámolni, így az egész rész nyolcadát kapjuk meg. Mivel a kérdés egy viszonyszám, a megoldás független a kiinduló 
kocka méretétől. Célszerű tehát az oldalélét 2 egységnyinek választani, így az átfúró henger sugara 1 egység lesz. Az a) elrendezés esetén egységnyi oldalú négyzet-tartományon kell integrálni két hengerfelületet, míg a b) esetben negyedkör tartományon kell integrálni egy hengerfelületet. Szükségünk van az $x$-, $y$ - és $z$-tengelyü hengerfelületek egyenletére, melyek a következők:

$$
\begin{aligned}
& x \text {-tengelyü hengerfelület: } y^{2}+z^{2}=1 \text {, } \\
& y \text {-tengelyü hengerfelület: } x^{2}+z^{2}=1 \text {, } \\
& z \text {-tengelyü hengerfelület: } x^{2}+y^{2}=1 \text {. }
\end{aligned}
$$

A feladat megoldását a

$$
\frac{V_{\text {megmaradó }}}{V_{\text {kocka }}}=\frac{V_{\text {kocka }}-2 V_{\text {henger }}+V_{\text {közös }}}{V_{\text {kocka }}}
$$

formula fogja szolgáltatni, amelyben

$$
\begin{aligned}
& V_{\text {kocka }}=(2 r)^{3}=2^{3}=8, \\
& V_{\text {henger }}=r^{2} \pi(2 r)=2 \pi .
\end{aligned}
$$

\section{1. megoldás}

Nézzük először az 1. ábra a) elrendezését. Az $x$ - és az $y$-tengelyü hengerek az $y=x$ és az $y=-x$ egyenletủ síkokban metszik egymást, melyeknek az $x y$-síkra eső vetülete ugyancsak az $y=x$ és az $y=-x$ egyenletü egyenesek. Az I. síknegyed vonalkázott tartománya felett az $y$-tengelyü henger helyezkedik el lentebb, míg a pöttyözött tartományon az $x$-tengelyü. Mindkét tartomány felett ugyanakkora térfogat van, ezért elegendő az egyiket számítani, s az eredményt 16-tal szorozni. Ez most a vonalkázott tartomány feletti rész lesz. Tehát feladatunk az, hogy az 1. a) ábrán látható vonalkázott háromszög tartományon integráljuk az y-tengelyü hengerfelületet, vagyis az

$$
z=f(x, y)=\sqrt{1-x^{2}}
$$

kétváltozós függvényt.

A két változó integrálási sorrendjétől függően kétféleképpen írhatjuk fel az integrált:

$$
V=\int_{0}^{1} \int_{0}^{y} \sqrt{1-x^{2}} d x d y
$$

vagy

$$
V=\int_{0}^{1} \int_{0}^{x} \sqrt{1-x^{2}} d y d x
$$

Az előbbi integrál esetében az

$$
x=\sin t
$$

helyettesítés alkalmazandó, amellyel kissé hosszabb és körülményesebb a számolás, míg az utóbbi integrál egészen egyszerúen elvégezhető.

$$
V=\int_{0}^{1} \int_{0}^{x} \sqrt{1-x^{2}} d y d x=\int_{0}^{1} \sqrt{1-x^{2}}[y]_{0}^{x} d x=\int_{0}^{1} x \sqrt{1-x^{2}} d x
$$


Az y változó szerinti integrálás után egy klasszikusnak mondható integrált kapunk. Egyik megoldási lehetőség az

$$
1-x^{2}=t
$$

helyettesítés. Másik lehetőség az, hogy a kifejezést megszorozzuk - 2-vel és el is osztunk vele:

$$
V=\int_{0}^{1} x \sqrt{1-x^{2}} d x=-\frac{1}{2} \int_{0}^{1}-2 x \sqrt{1-x^{2}} d x
$$

ekkor egy

$$
\int f^{n}(x) f^{\prime}(x) d x=\frac{f^{n+1}(x)}{n+1}+c
$$

alakú integrált kapunk, ahol

$$
\begin{aligned}
& f(x)=1-x^{2}, \\
& f^{\prime}(x)=-2 x, \\
& n=\frac{1}{2} .
\end{aligned}
$$

A megoldás:

$$
V=-\frac{1}{2}\left[\frac{\left(1-x^{2}\right)^{\frac{3}{2}}}{\frac{3}{2}}\right]_{0}^{1}=-\frac{1}{3}(0-1)=\frac{1}{3}
$$

Tehát a két átható henger közös részének térfogata

$$
V_{k o ̈ z o ̈ s}=16 \mathrm{~V}=\frac{16}{3} \text {. }
$$

A feladat megoldása pedig:

$$
\frac{V_{\text {megmaradó }}}{V_{\text {kocka }}}=\frac{8-4 \pi+\frac{16}{3}}{8}=\frac{5}{\underline{3}-\frac{\pi}{2}} .
$$

\section{2. megoldás}

Tekintsük most az 1. b) ábra szerinti elrendezést. A z-tengelyü henger $x y$-síkba eső vetülete nem más, mint az

$$
x^{2}+y^{2}=1
$$

egyenletü kör. Elegendő most is az I. síknegyedbe eső negyed körlapon integráli (vonalkázott tartomány). Az integrálandó függvény most is az $y$-tengelyü hengerfelület, azaz az (1) függvény. Az $x$ és $y$ változók szerinti integrálás sorrendje itt is kétféle lehet, de az előzőekben elmondottak alapján célszerü most is először $y$ azután $x$ szerint integrálni. Ez esetben az integrálási tartomány határvonalát jelentő negyed körív egyenletét a (3)-ból kifejezett

$$
y=\sqrt{1-x^{2}}
$$

függvény adja. 
A kiszámolandó kétváltozós integrál a következő:

$$
V=\int_{0}^{1} \int_{0}^{\sqrt{1-x^{2}}} \sqrt{1-x^{2}} d y d x .
$$

A számolás menete:

$$
\begin{aligned}
V=\int_{0}^{1} \int_{0}^{\sqrt{1-x^{2}}} \sqrt{1-x^{2}} d y d x=\int_{0}^{1} \sqrt{1-x^{2}}[y]_{0}^{\sqrt{1-x^{2}}} d x \\
\quad=\int_{0}^{1} \sqrt{1-x^{2}} \sqrt{1-x^{2}} d x=\int_{0}^{1}\left(1-x^{2}\right) d x=\left[x-\frac{x^{3}}{3}\right]_{0}^{1}=1-\frac{1}{3}=\frac{2}{3} .
\end{aligned}
$$

Ez a nyolcada a két henger közös részének, tehát a teljes közös rész térfogata 16/3.

Megjegyzés: könnyen félrecsúszhat a feladat megoldása, ha a körtartomány láttán az integrált síkbeli polárkoordinátákkal akarjuk felírni. A próbálkozást az olvasóra bízom.

\section{3. megoldás}

Egy következő megoldás további térlátást igényel. Tekintsük most csak a két átható hengert, valamint annak közös részét mint önálló testet (2. a) és b) ábra).

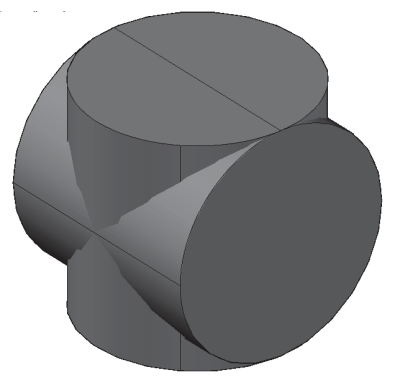

a)

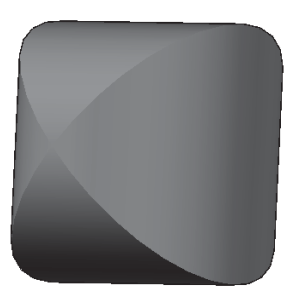

b)

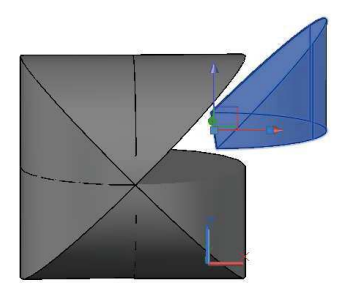

c)

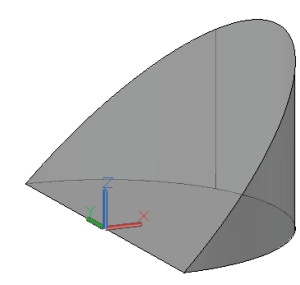

d)

2. ábra. A két egymásba tolt henger (a), közös részük (b) és a közös részt felépítő elemek (c), (d)

Vegyük észre, hogy a közös rész a 2. c) ábrán látható módon nyolc egybevágó kisebb testre bontható. Egy ilyen építőelemet a következő módon származtathatunk: messük el az egységsugarú, egységnyi magasságú hengert egy olyan síkkal, amely az alaplapjának egy átmérőjét tartalmazza, és az alaplappal 45 fokos szöget zár be. Az így kettévágott hengernek eltávolítjuk a sík fölé eső részét. A megmaradó alsó részt térfogatának meghatározásához a 2. d) ábrán látható módon helyezzük koordináta-rendszerbe. Az xy-síkkal 45 fokot bezáró, ytengelyt tartalmazó síkot megadó kétváltozós függvény:

$$
f(x, y)=x
$$

Ezt a függvényt kell integrálnunk az xy-sík pozitív síknegyedébe eső negyed körön, így a test térfogatának felét, a két henger közös részének pedig 1/16-át kapjuk.

$$
V=\int_{0}^{1} \int_{0}^{\sqrt{1-x^{2}}} x d x d y=\frac{1}{3}
$$

Az eredmény levezetését az olvasóra bízzuk. 


\section{4. megoldás}

Felmerül a kérdés, hogy ha már úgyis integrálnunk kell, miért nem írjuk fel közvetlenül a szita formula kihagyásával - a kocka megmaradó térfogatát. Ehhez az 1. a) ábra elrendezését használhatjuk. Elegendő most is az egyik háromszög tartomány fölött számolni, ez az eredmény 1/16-át adja. Míg a két henger közös részének kiszámolásakor a két henger közül a lentebb elhelyezkedőnek a felülete alatti térfogatot kell kiszámolnunk, úgy most a fentebbi henger felülete és a kocka felső lapja közötti térfogatot kell meghatároznunk. Válasszuk most a pöttyözött háromszöget, mely fölött az $y$-tengelyü hengerfelület helyezkedik el magasabban, melynek egyenletét (1) adja, míg a kocka felső lapjának egyenlete

$$
g(x, y)=1 \text {. }
$$

Az integrálást célszerủen először az y aztán az $x$ változó szerint hajtjuk végre.

$$
V=\int_{0}^{1} \int_{x}^{1}(g(x, y)-f(x, y)) d y d x=\int_{0}^{1} \int_{x}^{1}\left(1-\sqrt{1-x^{2}}\right) d y d x
$$

A számolás menete:

$$
V=\int_{0}^{1} \int_{x}^{1}\left(1-\sqrt{1-x^{2}}\right) d y d x=\int_{0}^{1}\left(1-\sqrt{1-x^{2}}\right)(1-x) d x
$$

A szorzást elvégezve és rendezve az integrandust a következő három tagra bontható az integrál:

$$
V=\underbrace{\int_{0}^{1}(1-x) d x}_{V_{1}}-\underbrace{\int_{0}^{1} \sqrt{1-x^{2}} d x}_{V_{2}}+\underbrace{\int_{0}^{1} x \sqrt{1-x^{2}} d x}_{V_{3}} .
$$

Az első tag:

$$
V_{1}=\int_{0}^{1}(1-x) d x=\left[x-\frac{x^{2}}{2}\right]_{0}^{1}=1-\frac{1}{2}=\frac{1}{2} .
$$

A második tagnál alkalmazhatjuk a kissé hosszadalmas $x=\sin t$ helyettesítést, de van egy más lehetőség is. Vegyük észre, hogy az integrandus nem más, mint egy origó középpontú egységsugarú kör, melyet a [0,1] intervallumon integrálva éppen a negyed kör területét kapjuk, értéke tehát $\pi / 4$. A harmadik tag pedig épen (2)-vel egyezik, értéke 1/3. A kapott eredményekkel a feladat megoldása:

$$
\frac{V_{\text {megmaradó }}}{V_{\text {kocka }}}=\frac{16 \mathrm{~V}}{V_{\text {kocka }}}=\frac{16\left(\frac{1}{2}-\frac{\pi}{4}+\frac{1}{3}\right)}{8}=\frac{8-4 \pi+\frac{16}{3}}{8}=\frac{5}{\underline{\underline{3}}-\frac{\pi}{2}} .
$$

Ez a hosszadalmas módszer ugyan nem tartalmazza azt az ötletet, amellyel a szitaformula segítségével egyszerübben jutunk el a megoldáshoz, mégis ugyanazt a számítást végeztuik el, hiszen $V_{1}$ a kocka, $V_{2}$ a két henger, $V_{3}$ pedig a két henger közös részének a térfogatát szolgáltatja. 


\section{A ,mérnök” megoldása.}

A feladat első megoldása alkalmával (2010 előtt) az átfúrt kocka a Solid Edge ST2 programmal lett megszerkesztve és a térfogat kiszámolva. Most a cikk írásakor az Autodesk Inventor 2015 és az Autodesk AutoCAD 2016 tervezőprogramok diákverzióit használtuk. A minél pontosabb eredmény elérése céljából a kocka élének hosszát 2000 mm-nek választottuk, míg a lyuk átméröjét 1999,98 mm-nek. Erre azért volt szükség, mert ha a lyuk átmérője egyezik a kocka oldalélének hosszával, akkor a kocka fizikailag szétesik résztestekre, és a program nem kezeli egy testként. A szerkesztés gyors és egyszerü volt, a számolás két gombnyomás. A kocka megmaradó térfogata:

$$
V_{\text {megmaradó }}=767054089,9292 \mathrm{~mm}^{3} \text {. }
$$

Vessük ezt össze a matematikai számítással kapott pontos eredménnyel:

$$
V_{\text {megmaradó }}=8-4 \pi+\frac{16}{3}=0,766962718 \text { térfogategység. }
$$

A mérnök által kiszámított eredmény a pontostól mindössze 0,012 \%-kal tér el.

\section{3. Összefoglaló}

Írásomban négy gondolatmenet alapján ismertettem a kitűzött feladat matematikai megoldási lehetőségeit. A közös bennük az, hogy a megmaradó rész térfogatát integrálszámítással határozzuk meg. Az első három megoldás a két átható henger közös részének térfogatát határozza meg, majd a szita-formulát alkalmazva kapjuk meg a megmaradó térfogatot. A negyedik megoldás közvetlenül a megmaradó térfogatot határozza meg, de ugyanúgy a szita-formula van benne elrejtve. Jól példázza ez azt, hogy ha nincs egy jó ötletünk, tervünk a megoldáshoz, sokszor akkor is ugyanazokat a lépéseket végigjárva jutunk el a végeredményhez, de kissé hosszadalmasabban, s esetleg rejtve marad előttünk, mit is számolunk éppen. A megoldásokban szereplő integrálok technikailag nem nehezek, talán minden olyan oktatási intézményben, ahol integrálszámítást oktatnak - beleértve a középiskolákat is - a tananyag részét képezik, így elvileg kiszámolhatók a tanultak alapján. Az igazi konstruktív gondolkodást magának az integrálnak a felírása jelenti, mely igényli a test elképzelésének képességét, azt, hogy hogyan célszerü azt a testet elhelyezni a koordinátarendszerben, valamint az alapvető felületek egyenleteinek ismeretét. Az előbbi két képesség fejleszthető, ha nem pusztán határozott integrálokat írunk fel megoldásra, hanem alapvető területeket, egyszerübb testek, csonkolt testek térfogatát számoltatjuk a hallgatókkal, szabadkézi vázlatot készíttetve velük. Ugyanakkor remekül alkalmazhatók szemléltetésre a tervezőprogramokkal elkészített ábrák.

A történetböl tanulságként levonható, hogy mindenki olyan eszközökhöz folyamodik egyegy probléma megoldása során, amelynek birtokában van: a „matektanár” a papíron való számoláshoz, a „technikus” a fúrógéphez és a precíziós mérleghez, a „mérnök” pedig a tervezőprogramhoz.

\section{Köszönetnyilvánítás.}

Ezúton szeretnék köszönetet mondani páromnak, Bakki-Nagy Imrének, aki annak idején faipari mérnökhallgatóként megrajzolta és kiszámolta a megmaradó kocka térfogatát, és most a cikk kedvéért újrarajzolta, számolta a feladatot az említett két újabb programmal. Továbbá köszönöm neki a cikk ábráinak elkészítését. 